\title{
Mister Pulitzer and the Spider: Modern News from Realism to the Digital
}

\author{
Kevin G. Barnhurst
}

University of Illinois Press, Urbana, IL

$2016 \$ 34.95$ (Hardcover), pp. 320

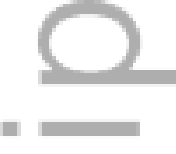

Kevin Barnhurst's Mister Pulitzer and the Spider successfully interweaves two distinct threads of exposition and narrative, with both contributing to why this book merits serious attention and informed appreciation from multiple sets of readers.

The first of the discussions is a cumulative summary of social scientific research that Barnhurst and associated scholars carried out across three decades to test the idea that a "new long journalism' could explain changes amidst continuities in the content and form of news that occurred from the $19^{\text {th }}$ century 'realist' news tradition to $20^{\text {th }}$ century 'modernism' and now into the $21^{\text {st }}$ century era of online and social media news. Barnhurst (1991) first identified and wrote about long journalism in the early 1990s; research documenting this change in news and reporting advanced during the succeeding decades to culminate in the present book, which extends the relevance of findings to the contemporary digital era. This contribution to knowledge building about media and journalism is a significant accomplishment that should receive commendation from media scholars as well as from professional journalists, while also attracting wider circles of those who wish to understand how news making has taken shape as an ideal and how it has actually measured up as professional practice.

This is the author manuscript accepted for publication and has undergone full peer review but has not been through the copyediting, typesetting, pagination and proofreading process, which may lead to differences between this version and the Version of Record. Please cite this article as doi: $10.1111 /$ jcom. 12255

This article is protected by copyright. All rights reserved. 
Barnhurst's second narrative presents the broader contexts of news, including impacts on and intersections with culture, politics, economics, and the quality of public and personal life. Here, Barnhurst reinforces his achieved reputation as a writer of considerable intellectual depth and rhetorical skill, who possesses extensive familiarity with sources ranging throughout the fields of literature, philosophy, art and aesthetics, and, of course, the classics of communication scholarship, especially topics related to the public sphere and civic life. Barnhurst applies this knowledge to construct a stimulating commentary and historical account concerning the development of U. S. news across years of challenge and change for the institution of the press. Also, as a long-time, leading commentator on practical and aesthetic dimensions of graphic design, especially newspaper design, Barnhurst combines a designer's sensibility with a "writerly" understanding of how to integrate description and narrative with epigrams, evocative chapter headings, diagrams and related elements to convey creative inspiration at the center of a recounting and explication of important social scientific data and findings. The result is a book that rewards close reading by everyone interested in how a first-rate intellect and writer, possessing a designer's judgment, goes about supporting the "bold claim" which orients his account: “... that texts as conveyors of ideas produced the modern world of the twentieth century."

Long news research proceeded from the observation that the definition of news changed in the 20th century. Content analysis of news articles from the years 1894-1994, taken from editions of three representative newspapers, explored how the traditional five Ws of reporting who, what, when, where, and why - were incorporated into writing and presentation of news. 
Nineteenth century realist news had established a storytelling approach that described concrete events (what); as these events occurred at specifiable dates and times (when); involving actual, nameable persons from diverse walks of life (who); while locating these persons at specific addresses of work and home or neighborhood life (where); and taking into account declared or observable motivations and intentions (why) when these helped to could convey the dramatic $=$ and informational point of the story. The five Ws were thought to ensure the objective realism of news reporting.

The 'why' was obviously the most subjective aspect of storytelling in the realist tradition, while $20^{\text {th }}$ century modernism tended to emphasize commentary about the likely 'whys' behind news. Key findings emerged about changes that occurred across the century in the articles that were examined: “...stories grew longer, included more analysis, expanded from specific locations to broader regions, placed more emphasis on time frames other than the present, and named fewer individuals and more groups, officials, and outside sources" (Barnhurst \& Mutz, 1997, p. 27). As the "basic recipe for news - the report of events new to the hearer" changed, so did the role of the journalist. Rather than mainly describing the $5 \mathrm{Ws}$, the modern journalist contributed far beyond reporting events, to become involved in commenting and attributing significance and meanings. Journalists as news experts took their elevated place among other categories of knowledge professionals in modern societies that had come to depend on expertise. The news market and the culture of professional journalism became oriented towards interpretation, sense making, and lengthy analysis of context and social issues as core skills of news practices. 
The book presents these arguments through sections arranged according to the categorical logic that informed the content analysis of news reports for the research. The section on 'who' finds that "people disappeared as news [length] expanded"; the "what' of reporting underwent change as "events, the basic stuff of news declined"; 'where' surpassed the local as "locations for news grew more remote"; and 'when' came to illustrate how "the now of news pursued modernism"; in terms of reporting on 'why' questions, the ascendency of modernism meant that “against all odds, interpretation advanced."

Readers are summoned to recognize how the $20^{\text {th }}$ century modern world of news, which many would say we can observe receding in the rear view mirror of journalism history, may still be very much with us in its most basic professional and ideological commitments. In Barnhurst's account, the same modernism that Mister Pulitzer first "imagined" in the 1880s as his dream for future journalism was pursued into the 1900s as a governing ideal for news, and has now itself become, in the $21^{\text {st }}$ millennium, the contemporary old way that refuses to be left behind as online communication reaches towards what often can seem like other-worldly dreams of a wholly transformed communications ideal based on the supposed democratic force and influence of ever-advancing technologies and media. Present understandings and practices of news actually operate equivocally in the present interregnum. Barnhurst suggests that the web, as envisioned in all its promising possibilities, should be regarded, alternatively, as a metaphorical spider, since it weaves patterns that may appear to follow the symbolic order we wish to imagine, create, and construct, but that could instead bespeak qualities of consciousness and conscience we can only dimly comprehend from where our knowledge and inspiration now position us. The present 
moment for journalism is a time/space - real and virtual -- of opportunity certainly, but also of danger. Still, Barnhurst concludes by counseling optimism, that today's and tomorrow's “journalism as a system ... could possibly foster general knowledge another way, by recording real events in the locations of everyday life, telling the stories of, by, and for the people."

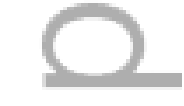

$=$

Wayne D. Woodward

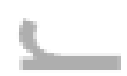

University of Michigan-Dearborn

\section{References}

Barnhurst, K. G. (1991). The great American newspaper. American Scholar 60(1) Winter, 106112.

Barnhurst, K. G. \& Mutz, D. (1997). American journalism and the decline in event-centered reporting. Journal of Communication, 47(4), 27-52.

Nerone, J. \& Barnhurst, K. G. (2001). The form of the news: A history. New York: The Guilford Press.

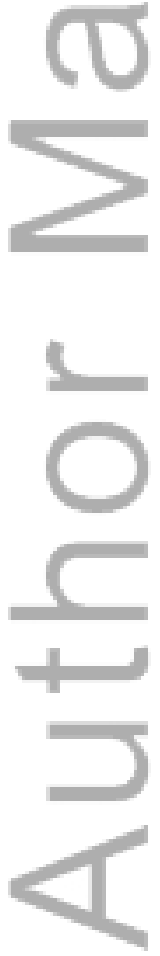

This article is protected by copyright. All rights reserved. 